\title{
The Rate of Recombination Repair and its Relationship to the Radiation-induced Delay in DNA Synthesis in Micrococcus radiodurans
}

\author{
By B. E. B. MOSELEY AND H. J. R. COPLAND \\ Department of Microbiology, University of Edinburgh, School of Agriculture, \\ Edinburgh $\mathrm{EH}_{9}{ }_{3} \mathrm{JG}$
}

(Received 15 April 1975; revised 8 October 1975)

\begin{abstract}
SUMMARY
The measurement of the time at which normal colony-forming ability returns in irradiated cultures of Micrococcus radiodurans ts 1 held at $30^{\circ} \mathrm{C}$ can be used to estimate the time of completion of recombination repair. By comparing the times to complete such repair in populations given increasing radiation doses it is possible to calculate the rate of recombination repair. The rate was independent of the radiation dose; recombination could repair in one minute the damage caused either by $1.2 \mathrm{krad}$ gamma radiation or $4 \times 10^{-6} \mathrm{~J} \mathrm{~mm}^{-2}$ u.v. radiation.

The time taken for the normal rate of DNA synthesis to return in irradiated $M$. radiodurans ts I was measured under conditions identical to those used to measure recombination repair. The delay in DNA synthesis was $\mathrm{I} \cdot 0$ min per $\mathrm{I} \cdot 2$ $\mathrm{krad}$ gamma radiation and $\mathrm{I} \cdot 0 \mathrm{~min}$ per $5.6 \times 10^{-6} \mathrm{~J} \mathrm{~mm}^{-2} \mathrm{u}$.v. radiation. The data suggest that the normal rate of DNA synthesis resumes immediately after the completion of recombination repair of gamma-induced damage, but before the completion of recombination repair of u.v.-induced damage. It is postulated that cell death at the lethal dose of u.v. radiation is caused by a second round of replication of DNA which is still being repaired by recombination.
\end{abstract}

\section{INTRODUCTION}

The vegetative bacterium Micrococcus radiodurans is extremely resistant to the lethal effect of ionizing and u.v. radiation (Anderson et al., 1956; Duggan et al., 1959). This property is dependent on a very efficient recombination repair mechanism (Moseley, Mattingly \& Copland, 1972a; Moseley \& Copland, 1975a) and, to a lesser extent, an excision process (Boling \& Setlow, 1966) which between them cope with extensive $\gamma$ radiationinduced DNA strand breakage and u.v. radiation-induced pyrimidine dimer formation.

The temperature-sensitive mutant $M$.radiodurans ts I has the same resistance to radiation as the wild type at $30{ }^{\circ} \mathrm{C}$, indicating that it has wild-type repair capacity at the permissive temperature. However, if it is raised to its restrictive temperature of $39{ }^{\circ} \mathrm{C}$, DNA synthesis stops immediately (Moseley, Mattingly \& Shimmin, 1972b) and it gradually becomes sensitized to both ionizing and u.v. radiation. The rate of loss of radiation resistance has been correlated with the rate of loss of a recombination function when the culture is held at $39{ }^{\circ} \mathrm{C}$ (Moseley et al., 1972a).

Sublethally-irradiated populations of $M$. radiodurans ts I give rise to colonies identical to those derived from unirradiated populations if they are incubated at $30{ }^{\circ} \mathrm{C}$. However, if they are exposed to the restrictive temperature of $39{ }^{\circ} \mathrm{C}$ for $3 \mathrm{~h}$ (restrictive temperature holding) before incubation at $30{ }^{\circ} \mathrm{C}$, more than $99 \%$ of the irradiated bacteria produce 
small, grossly abnormal colonies which, in their early development, are composed entirely of giant cells. It appears, therefore, that the recombination function which is depleted at $39{ }^{\circ} \mathrm{C}$, is required not only for the repair of radiation damage, but also for the regulation of cell division (Moseley \& Copland, $1975 b$ ).

Irradiated populations of $M$. radiodurans ts I only give rise to a high frequency of abnormal colonies if they are subjected to restrictive temperature holding when the recombination function is actively involved in the repair of the radiation-induced damage. This provides a method of timing recombination repair, since the population will only become resistant to the effects of restrictive temperature holding when recombination repair is complete. The time taken for recombination to occur at $30^{\circ} \mathrm{C}$ has been measured for a range of non-lethal doses of ionizing and u.v. radiation, and a rate for recombination repair calculated. This has been compared with another parameter of DNA repair, namely the radiation-induced delay in DNA synthesis.

\section{METHODS}

Organism. Micrococcus radiodurans ts I (Moseley et al., 1972b).

Media. TGY medium for growth contained ( $\mathrm{g} / \mathrm{l}$ distilled water): Bacto-tryptone (Difco), 5; glucose, I; yeast extract (Difco), 3. TGY agar was made by solidifying this medium with I5 g Bacto-agar/l. The $0.067 \mathrm{M}$-phosphate buffer $\mathrm{pH} 7.0$ contained $4.73 \mathrm{~g} \mathrm{Na}_{2} \mathrm{HPO}_{4}$ and $4.54 \mathrm{~g} \mathrm{KH}_{2} \mathrm{PO}_{4} / 1$ distilled water.

Growth of bacteria. Bacteria were grown in $20 \mathrm{ml}$ quantities of TGY broth in $250 \mathrm{ml}$ conical flasks which were swirled at $30^{\circ} \mathrm{C}$ until the extinction was between 0.25 and 0.30 on an EEL nephelometer with an orange filter. This was equivalent to a concentration of $8 \times 10^{7}$ to $9 \times 10^{7}$ viable units $/ \mathrm{ml}$.

Irradiation of bacteria. Samples ( $10 \mathrm{ml}$ ) of the bacteria were washed and resuspended in phosphate buffer at a concentration of about $10^{8}$ viable units $/ \mathrm{ml}$. For u.v. irradiation a $5 \mathrm{ml}$ sample of the washed bacterial suspension in a $9 \mathrm{~cm}$ Petri dish was agitated with a magnetic stirrer at a distance of $40 \mathrm{~cm}$ from a Hanovia model $\mathrm{r} 2$ germicidal lamp (incident dose rate $2.25 \times 10^{-6} \mathrm{~J} \mathrm{~mm}^{-2} \mathrm{~s}^{-1}$ ). Gamma irradiation was carried out in a ${ }^{60} \mathrm{Co}$ source at a dose rate of 5 to $6 \mathrm{krad} \mathrm{min}^{-1}$. Portions $(3 \mathrm{ml})$ of the washed suspension were irradiated, oxygen being bubbled during the irradiation.

The effect of restrictive temperature holding on irradiated populations of $M$. radiodurans tsi after increasing times of incubation at $30^{\circ} \mathrm{C}$. After exposure to a single dose of radiation ten samples of the irradiated suspension were diluted immediately into fresh TGY medium at $30{ }^{\circ} \mathrm{C}$. Two dilution factors were used, roo-fold (0.1 ml into $9.9 \mathrm{ml}$ TGY) and fivefold $(2 \mathrm{ml}$ into $8 \mathrm{ml}$ ). Details are given in the Figure legends and in Results. These cultures were incubated at $30^{\circ} \mathrm{C}$ on a reciprocating shaker immersed in a water bath for times ranging from 0 to $240 \mathrm{~min}$ after irradiation, when they were shifted to $39^{\circ} \mathrm{C}$. When each culture had been incubated at $39^{\circ} \mathrm{C}$ for $3 \mathrm{~h}$, suitable dilutions were made in TGY medium and o. I ml amounts of each dilution were spread on the surface of TGY agar plates. Normal colonies were counted after incubation for two days and abnormal colonies after four days at $30{ }^{\circ} \mathrm{C}$. A graph was then plotted on semi-logarithmic paper of the return of normal colony-forming ability as a function of time at $30^{\circ} \mathrm{C}$.

Delay in the recovery of normal colony-forming ability as a function of the radiation dose. The above treatment was carried out on populations given increasing doses of u.v. and $\gamma$ radiation and the results plotted. The times taken for $10 \%$ of each irradiated population to recover normal colony-forming ability were obtained from the graphs. The difference in 
time for two cultures given different radiation doses to recover normal colony-forming ability in $10 \%$ of the population was taken to be the time required for the recombination repair of the extra radiation damage in the more heavily irradiated culture.

Delay in DNA synthesis as a function of the radiation dose. Samples of unirradiated and irradiated suspensions, exposed to increasing non-lethal doses of radiation, were diluted fivefold into $0.2 \mathrm{ml}$ TGY containing Io $\mu \mathrm{Ci}\left[6-{ }^{3} \mathrm{H}\right]$ thymidine $(26 \mathrm{Ci} / \mathrm{mmol})$ in test tubes. These were incubated at $30{ }^{\circ} \mathrm{C}$ on a reciprocating shaker, and at suitable intervals $10 \mu \mathrm{l}$ samples were removed and assayed for radioactivity in the trichloroacetic acid (TCA)insoluble fraction of the cell, as described previously (Moseley, I969).

\section{RESULTS}

\section{Recovery of normal colony-forming ability in irradiated populations of $M$. radiodurans tsI}

The effect on colony formation of u.v.-irradiating a population of $M$. radiodurans ts $I$ and holding it in TGY medium at $30^{\circ} \mathrm{C}$ for increasing lengths of time before subjecting it to restrictive temperature holding is shown in Fig. I. When a culture given a non-lethal dose of $2.64 \times 10^{-4} \mathrm{~J} \mathrm{~mm}^{-2}$ was subjected to restrictive temperature holding immediately after irradiation, $1.4 \%$ of the population gave rise to normal colonies and $98.6 \%$ to abnormal colonies. During the first $60 \mathrm{~min}$ after irradiation the proportion of the population giving rise to normal colonies fell to $0.6 \%$, but after $70 \mathrm{~min}$ it started to increase exponentially to a maximum value of about $40 \%$ of the total population, attained approximately $180 \mathrm{~min}$ after irradiation. The proportion did not rise above $40 \%$ because the restrictive temperature holding procedure caused $60 \%$ of all cultures, including unirradiated control populations, to form abnormal colonies. No explanation has been sought for the initial drop in the proportion of normal colonies during the first 60 min after irradiation.

\section{Delay in recovery of normal colony-forming ability as a function of dose}

The time of recovery of normal colony-forming ability was dose-dependent. In Fig. 1 the effect of a u.v. dose of $\mathrm{I} \cdot 32 \times \mathrm{IO}^{-4} \mathrm{~J} \mathrm{~mm}^{-2}$ on normal colony formation is compared with a u.v. dose of $2.64 \times \mathrm{IO}^{-4} \mathrm{~J} \mathrm{~mm}^{-2}$. The ability of $10 \%$ of the irradiated bacteria to give rise to normal colonies was recovered 33 min earlier when the u.v. dose was $\mathrm{I} \cdot 32 \times 10^{-4} \mathrm{~J} \mathrm{~mm}^{-2}$ than when it was $2.64 \times 10^{-4} \mathrm{~J} \mathrm{~mm}^{-2}$, i.e. the delay in recovery time was $1 \cdot 0$ min per $4^{\circ} 0 \times 10^{-6}$ $\mathrm{J} \mathrm{mm}^{-2}$ u.v.radiation. The effect on normal colony formation of 30 and $\mathrm{I} 00 \mathrm{krad} \gamma$ radiation is shown in Fig. 2. There was a similar dose dependence. The recovery of the ability to give rise to normal colonies in $10 \%$ of the population occurred 57 min earlier in bacteria given $30 \mathrm{krad}$ than in those given $100 \mathrm{krad}$, i.e. I.0 min per I. $2 \mathrm{krad}$. These results were obtained in identical experiments, the irradiated culture having been diluted initially roo-fold.

To make the results directly comparable with those measuring the radiation-induced delay in DNA synthesis, similar experiments were performed when the irradiated cultures were diluted fivefold. The time differences between the curves obtained with different doses were unaltered. In a series of experiments, we constructed sets of curves similar to those of Figs. I and 2, and compared the times for 10 \% of irradiated populations to recover their ability to give normal colonies following increasing radiation doses. It was not possible to study doses below $\mathrm{I} \cdot 32 \times 10^{-4} \mathrm{~J} \mathrm{~mm}^{-2}$ u.v. radiation or $30 \mathrm{krad} \gamma$ radiation because there was an inadequate loss of normal colony-forming ability. These doses were used, therefore, as the minimum comparative doses. The results of several experiments are summarized in Table $\mathrm{I}$. The difference in the times for $10 \%$ of the irradiated population to recover normal 


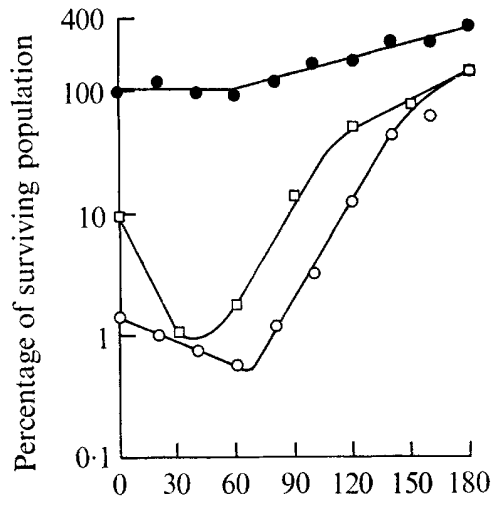

Time (min) at $30^{\circ} \mathrm{C}$, after irradiation

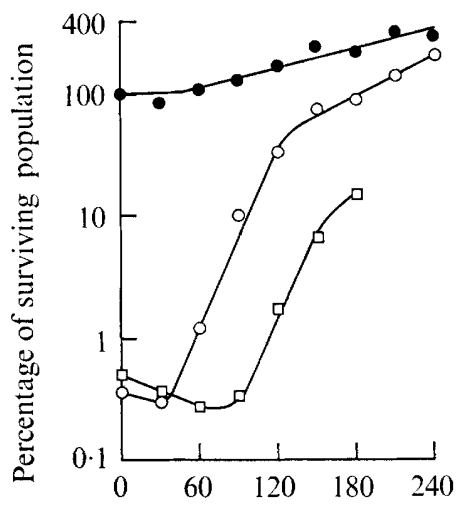

Time (min) at $30^{\circ} \mathrm{C}$, after irradiation

Fig. I

Fig. I. The effect of u.v. irradiation doses of $\mathrm{I} \cdot 32 \times 10^{-4}(\square)$ and $2.64 \times 10^{-4}(O) \mathrm{J} \mathrm{mm}^{-2}$ on the return of normal colony-forming ability in cultures of $M$. radiodurans ts $\mathrm{I}$ held at $30{ }^{\circ} \mathrm{C}$ following irradiation. The ability to give rise to normal colonies was tested by incubating the bacteria at $39^{\circ} \mathrm{C}$ for $3 \mathrm{~h}$ before plating. The total number of colonies, normal and abnormal, for the $2.64 \times \mathrm{IO}^{-4} \mathrm{~J} \mathrm{~mm}^{-2}$ dose is included (O). The irradiated cultures were diluted Ioo-fold.

Fig. 2. The effect of $\gamma$ radiation doses of $30(O)$ and IOo ( $\square$ ) krad on the return of normal colonyforming ability in cultures of $M$. radiodurans ts I held at $30^{\circ} \mathrm{C}$ following irradiation. The ability to give rise to normal colonies was tested by incubating the bacteria at $39^{\circ} \mathrm{C}$ for $3 \mathrm{~h}$ before plating. The total number of colonies, normal and abnormal, for the $30 \mathrm{krad}$ dose is included (O). The irradiated cultures were diluted roo-fold.

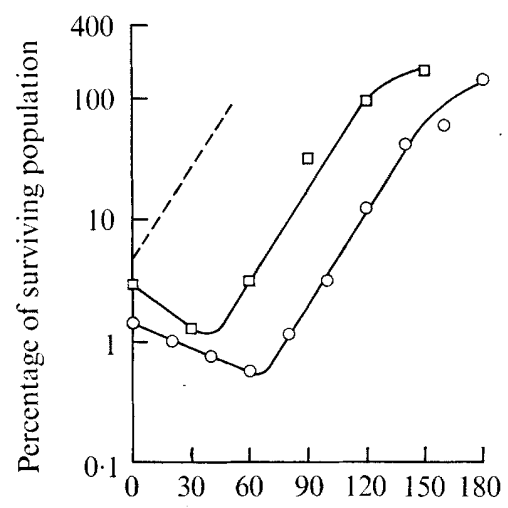

Time (min) at $30^{\circ} \mathrm{C}$, after irradiation

Fig. 3. The effect of a fivefold $(\square)$ or Ioo-fold $(O)$ dilution on the return of normal colony-forming ability in $M$. radiodurans ts I given an initial dose of $2.64 \times 10^{-4} \mathrm{~J} \mathrm{~mm}^{-2}$ and held at $30^{\circ} \mathrm{C}$. The ability to give rise to normal colonies was tested by incubating the bacteria at $39{ }^{\circ} \mathrm{C}$ for $3 \mathrm{~h}$ before plating. The derivation of the theoretical line (--) is given in the text. 
Table I. Differences in the recovery times of normal colony-forming ability in $M$. radiodurans ts i cultures given different irradiation doses

\begin{tabular}{|c|c|c|}
\hline $\begin{array}{l}\text { Radiation doses } \\
\text { compared }\end{array}$ & $\begin{array}{l}\text { Difference in time } \\
\text { for recovery of } \\
\text { normal colony-forming } \\
\text { ability in Io } \% \text { of } \\
\text { the population }\end{array}$ & $\begin{array}{l}\text { Radiation dose } \\
\text { inducing damage } \\
\text { repaired per minute }\end{array}$ \\
\hline $\begin{array}{l}\mathrm{IO}^{-4} \times \text { u.v. radiation } \\
\left(\mathrm{J} \mathrm{mm}^{-2}\right)\end{array}$ & $(\min )$ & $\left(\mathrm{IO}^{-6} \times \mathrm{J} \mathrm{mm}^{-2}\right)$ \\
\hline$I \cdot 32,2 \cdot 64$ & $33 \cdot 0$ & 4.0 \\
\hline $\mathrm{I} \cdot 32, \mathrm{I} \cdot 98$ & $18 \cdot 5$ & $3 \cdot 7$ \\
\hline $1 \cdot 98,2 \cdot 64$ & $16 \cdot 5$ & 4.0 \\
\hline$I \cdot 32,2 \cdot 64$ & $31 \cdot 0$ & $4 \cdot 3$ \\
\hline $2 \cdot 64,3 \cdot 96$ & $36 \cdot 0$ & $3 \cdot 7$ \\
\hline$I \cdot 32,2 \cdot 64$ & $30 \cdot 0$ & $4 \cdot 4$ \\
\hline $2 \cdot 64,3.96$ & $37 \cdot 0$ & $3 \cdot 6$ \\
\hline$\gamma$ Radiation (krad) & $(\min )$ & (krad) \\
\hline 30,100 & $57 \cdot 0$ & $1 \cdot 23$ \\
\hline 30,75 & $40 \cdot 0$ & $I \cdot I 3$ \\
\hline 75,120 & $40 \cdot 0$ & $\mathrm{I} \cdot \mathrm{I} 3$ \\
\hline
\end{tabular}

colony-forming ability was $\mathrm{I} \cdot 0$ min for either $4 \cdot 0 \times \mathrm{I}^{-6} \mathrm{~J} \mathrm{~mm}-2$ u.v. radiation or $\mathrm{I} \cdot 2 \mathrm{krad}$ of $\gamma$ radiation, these values being constant over the dose ranges studied.

Although the time difference for the delays in the return of normal colony formation in two populations of ts I given different irradiation doses was identical whether the bacteria were diluted 100-fold or fivefold, normal colony formation returned about 40 min earlier in an irradiated culture diluted fivefold than when diluted Ioo-fold (Fig. 3). This dilution effect was independent of dose and applied to both u.v. and ionizing radiation.

Because of limitations imposed by the method, the rate of recombination repair can only be shown to be constant once minimum doses of $\mathrm{I} \cdot 32 \times 10^{-4} \mathrm{~J} \mathrm{~mm}^{-2} \mathrm{u}$.v. radiation or $30 \mathrm{krad}$ $\gamma$ radiation have been given to cultures. However, if rate of recombination repair of u.v.-induced damage, derived from higher doses, is such that the damage induced by $4.0 \times 10^{-6} \mathrm{~J} \mathrm{~mm}^{-2}$ is repaired per min, and we assume this rate to be constant from time zero, then the recombination repair of the damage induced by $2.64 \times 10^{-4} \mathrm{~J} \mathrm{~mm}^{-2}$ u.v. radiation should be completed in $66 \mathrm{~min}$. If this time is subtracted from the experimental line for the return of normal colony-forming ability in a culture given a u.v. dose of $2.64 \times 10^{-4} \mathrm{~J} \mathrm{~mm}^{-2}$ and diluted only fivefold, the theoretical line shown in Fig. 3 is obtained. It indicates that recombination repair began immediately after irradiation, since the theoretical line rises from time zero. The intercept value on the ordinate suggests that some repair may have occurred before dilution. However, in the culture diluted I00-fold, either repair began 30 to $40 \mathrm{~min}$ after irradiation and then proceeded at a constant rate or it began at a slower rate and was only able to attain the rate at which the damage induced by $4 \cdot 0 \times 10^{-6} \mathrm{~J} \mathrm{~mm}^{-2}$ u.v. radiation was repaired per minute by about $70 \mathrm{~min}$.

\section{Radiation-induced delay in DNA synthesis}

Following the sublethal irradiation of an exponentially-growing culture of $M$. radiodurans ts I, there is a reduction in the rate of DNA synthesis to almost zero, but this gradually increases and reaches the control rate of an unirradiated culture. The delay in DNA synthesis is taken to be the difference in time for an unirradiated and irradiated population to incorporate the same amount of $\left[{ }^{3} \mathrm{H}\right]$ thymidine (I000 c p.m.) into the TCA-insoluble 


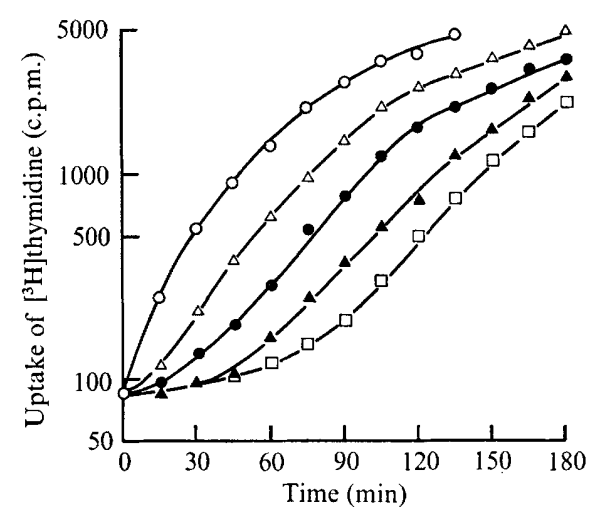

Fig. 4

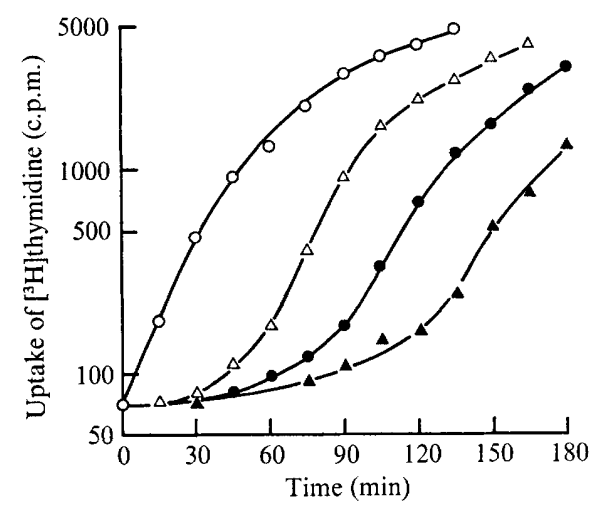

Fig. 5

Fig. 4. Radiation-induced delay of DNA synthesis in $M$. radiodurans ts I following u.v. doses of $\mathrm{O}(\mathrm{O}), \mathrm{I} \cdot 32 \times \mathrm{IO}^{-4}(\triangle), 2.64 \times 10^{-4}(\bigcirc), 3.96 \times 10^{-4}(\Delta)$ and $5.28 \times 10^{-4}(\square) \mathrm{J} \mathrm{mm}^{-2}$.

Fig. 5. Radiation-induced delay of DNA synthesis in $M$. radiodurans ts 1 following $\gamma$ radiation doses of $0(O), 50(\triangle), \mathrm{IOO}(\boldsymbol{O})$ and $150(\Delta) \mathrm{krad}$.

fraction of the cells, provided that the irradiated culture has reached the same incorporation rate as the unirradiated. Thus the radiation-induced delay is the time taken for the normal rate of DNA synthesis to return. With both u.v. and $\gamma$ radiation the delay in DNA synthesis is directly proportional to the radiation dose. For u.v. radiation, the delay in DNA synthesis caused by sublethal doses of $5.28 \times 10^{-4} \mathrm{~J} \mathrm{~mm}^{-2}$ or less is shown in Fig. 4. There was a delay of $24 \mathrm{~min}$ per $\mathrm{I} \cdot 32 \times \mathrm{IO}^{-4} \mathrm{~J} \mathrm{~mm}^{-2} \mathrm{u}$.v. radiation, equivalent to $\mathrm{I} \cdot 0 \mathrm{~min}$ per $5.6 \times \mathrm{IO}^{6} \mathrm{~J} \mathrm{~mm}^{-2}$ u.v. radiation. This linear relationship between the u.v. radiation dose and delay in DNA synthesis is valid for doses as high as $1 \cdot 05 \times 10^{-3} \mathrm{~J} \mathrm{~mm}^{-2}$. Data for the delay in DNA synthesis following $\gamma$ irradiation are in Fig. 5. For every $50 \mathrm{krad}$ increase in $\gamma$ radiation dose, the delay in DNA synthesis increased by $42.5 \mathrm{~min}$, this being equivalent to a delay of $\mathrm{I} \cdot 0 \mathrm{~min}$ per $\mathrm{I} \cdot 2 \mathrm{krad}$.

\section{DISCUSSION}

The time of recovery of normal colony-forming ability in irradiated populations of $M$. radiodurans ts is dose-dependent and provides a biological end-point for measuring the rate of recombination repair of radiation-induced damage. The time of recovery being measured is not necessarily the completion of recombination repair, since the recombination function defective in tsi has not been identified. Indirect evidence suggests that it may be similar in function to the recA gene product of Escherichia coli (Moseley \& Copland, $1975 b$ ). Therefore, the method identifies the end of the involvement of the recombination function in the repair of radiation damage, and the difference in time for this step to be completed in populations given increasing radiation doses indicates the rate of recombination repair, namely that recombination repairs in one minute the damage induced by $4.0 \times \mathrm{IO}^{-6} \mathrm{~J} \mathrm{~mm}^{-2}$ u.v. radiation or $\mathrm{I} \cdot 2 \mathrm{krad} \gamma$ radiation. It has been demonstrated that this rate of repair is constant for sublethal doses up to $3.96 \times 10^{-4} \mathrm{~J} \mathrm{~mm}^{-2}$ u.v. radiation and $\mathrm{I} 20 \mathrm{krad} \gamma$ radiation. Using this method, it is not possible to demonstrate directly whether this rate of recombination operates from time zero after irradiation. However, Lett et al. (I967) showed that in $\left[{ }^{3} \mathrm{H}\right]$ thymidine-labelled wild-type $M$. radiodurans the repair of sublethal damage induced by X-rays was associated with the partial breakdown of DNA into perchloric acid-soluble material. The extent of the breakdown was dose-dependent but its rate was dose-independent, 
being constant at $0.12 \%$ of the DNA label per minute. The breakdown started immediately after irradiation and continued until maximum release was reached, and only then did DNA synthesis resume. Lett et al. (1967) were presumably studying the breakdown of DNA associated with the activity of recombination-dependent repair, and it is reasonable to assume from this that the rate of recombination repair of damage induced by ionizing radiation is constant from time zero. The evidence for recombination repair of u.v. radiationinduced damage beginning at time zero and continuing at a constant rate is less direct, but from a consideration of the theoretical line in Fig. 3 it is not unreasonable to assume that it does.

To measure DNA synthesis at short times after irradiation we used initially unlabelled bacteria, so that small amounts of synthesis would give relatively large increases in radioactive counts (Setlow \& Setlow, 1970). The results confirmed previous findings that there is a delay in DNA synthesis which is linearly related to the radiation dose (Setlow \& Boling, I965; Dean, Feldschreiber \& Lett, 1966). Under comparable conditions to those used to measure the rate of recombination repair the delay was $\mathrm{I} \cdot 0 \mathrm{~min}$ per $5.6 \times \mathrm{IO}^{-6} \mathrm{~J} \mathrm{~mm}^{-2}$ u.v. radiation and $\mathrm{I} \cdot 0 \mathrm{~min}$ per $\mathrm{I} \cdot 2 \mathrm{krad} \gamma$ radiation. Since for $\gamma$ radiation, recombination repaired the damage induced by $\mathrm{I} \cdot 2 \mathrm{krad}$ per min the data suggest that DNA synthesis resumes immediately recombination repair is complete. A similar situation exists in E. coli, in which it has been demonstrated that the $\operatorname{rec} A$ gene product required in the slow repair of DNA single strand breaks introduced by $\gamma$ irradiation (McGrath \& Williams, 1966; Kapp \& Smith, 1970) acts before DNA replication (Gray, Green \& Bridges, 1972).

For u.v. radiation, however, recombination repairs the damage induced by $4.0 \times 10^{-6}$ $\mathrm{J} \mathrm{mm}^{-2}$ in one minute while the delay in DNA synthesis is only $1.0 \min$ per $5.6 \times \mathrm{IO}^{-6} \mathrm{~J} \mathrm{~mm}^{-2}$, indicating that DNA synthesis resumes before recombination is complete. Resumption of DNA synthesis before the completion of excision repair leads to the formation of DNA strand gaps which are the substrate for recombination repair enzymes (Rupp \& HowardFlanders, 1968). It is possible that cell death following doses of more than $\mathrm{I} \cdot 22 \times \mathrm{IO}^{-3} \mathrm{~J} \mathrm{~mm}^{-2}$ u.v. radiation is caused by a second round of replication of DNA which is still being repaired by recombination.

We thank Miss Diana Sweet for helpful criticism and valuable discussion in preparing the text. This work was supported by a grant from the Medical Research Council.

\section{REFERENCES}

Anderson, A. W., Nordan, H. C., Cain, R. F., Parrish, G. \& Duggan, D. (1956). Studies on a radioresistant micrococcus. Isolation, morphology, cultural characteristics and resistance to gamma radiation. Food Technology ro, 575-578.

Boling, M. E. \& SetLow, J. K. (I966). The resistance of Micrococcus radiodurans to ultraviolet radiation. III. A repair mechanism. Biochimica et biophysica acta 123, 26-33.

Dean, C. J., Feldschreiber, P. \& LetT, J. T. (I966). Repair of X-ray damage to the deoxyribonucleic acid in Micrococcus radiodurans. Nature, London 209, 49-52.

Duggan, D. E., Anderson, A. W., Elliker, P. R. \& Cain, R. F. (1959). Ultraviolet exposure studies on a gamma-radiation resistant micrococcus isolated from food. Food Research 24, 376-382.

Gray, W. J. H., Green, M. H. L. \& Bridges, B. A. (1972). DNA synthesis in gamma-irradiated recombination deficient strains of Escherichia coli. Journal of General Microbiology 71, 359-366.

KAPP, D. J. \& SMITH, K. C. (1970). Repair of radiation-induced damage in Escherichia coli. II. Effect of rec and $u v r$ mutations on radiosensitivity and repair of X-ray induced single strand breaks in deoxyribonucleic acid. Journal of Bacteriology 103, 49-54.

Lett, J. T., Feldschreiber, P., Little, J. G., Steele, K. \& Dean, C. J. (1967). The repair of X-ray damage to the deoxyribonucleic acid in Micrococcus radiodurans; a study of the excision process. Proceedings of the Royal Society B $167,184-20 \mathrm{r}$. 
McGrath, R. A. \& Williams, R. W. (1966). Reconstruction in vivo of irradiated Escherichia coli deoxyribonucleic acid; the rejoining of broken pieces. Nature, London 212, 534-535.

Moseley, B. E. B. (1969). Repair of ultraviolet radiation damage in sensitive mutants of Micrococcus radiodurans. Journal of Bacteriology 97, 647-652.

Moseley, B. E. B. \& Copland, H. J. R. (1975a). Isolation and some properties of a recombination deficient mutant of Micrococcus radiodurans. Journal of Bacteriology I2I, 422-428.

Moseley, B. E. B. \& Copland, H. J. R. (I975b). Involvement of a recombination repair function in disciplined cell division of Micrococcus radiodurans. Journal of General Microbiology 86, 343-357.

Moseley, B. E. B., Mattingly, A. \& Copland, H. J. R. (1972a). Sensitization to radiation by loss of recombination ability in a temperature-sensitive DNA mutant of Micrococcus radiodurans held at its restrictive temperature. Journal of General Microbiology 72, 329-338.

Moseley, B. E. B., Mattingly, A. \& Shimmin, M. (1972 b). Isolation and some properties of temperaturesensitive mutants of Micrococcus radiodurans defective in DNA synthesis. Journal of General Microbiology 70, 399-409.

Rupp, W. D. \& Howard-Flanders, P. (1968). Discontinuities in the DNA synthesized in an excision defective strain of Escherichia coli following ultraviolet irradiation. Journal of Molecular Biology 3r, 29I-304.

Setlow, J. K. \& Boling, M. E. (1965). The resistance of Micrococcus radiodurans to ultraviolet radiation. II. Action spectra for killing, delay in DNA synthesis and thymine dimerization. Biochimica et biophysica acta 108, 259-265.

SetLow, R. B. \& SetLow, J. K. (I970). Macromolecular synthesis in irradiated bacteria. Mutation Research 9, 434-436. 